\title{
Optimization of culture conditions for short-term maintenance, proliferation, and colony formation of porcine gonocytes
}

\author{
Awang Hazmi Awang-Junaidi and Ali Honaramooz ${ }^{*}$ (D)
}

\begin{abstract}
Background: Gonocytes give rise to spermatogonial stem cells, and thereby play an essential role in establishing spermatogenesis. Optimized culture conditions for gonocytes provide an opportunity for their study and in vitro manipulation for potential application in reproductive technologies. Using six experiments in a step-wise design, we examined the effects of several culture conditions on the maintenance, proliferation, and colony formation of porcine gonocytes. Testis cells from neonatal piglets were cultured for $7 \mathrm{~d}$ in DMEM supplemented with $10 \%$ fetal bovine serum. The examined culture conditions included using different cell seeding densities, gonocyte proportions, incubation temperatures, sampling strategies, and medium changing regimens.

Results: Confluency of cells was optimal (>90\% by $\sim 6 \mathrm{~d}$ ) when $3.0 \times 10^{4}$ testis cells $/ \mathrm{cm}^{2}$ containing $\sim 40 \%$ gonocytes were used. Incubating the cells at $35^{\circ} \mathrm{C}$ or $37^{\circ} \mathrm{C}$ resulted in similar cell number and viability at confluency, but incubation at $35^{\circ} \mathrm{C}$ resulted in a delayed confluency. In the first $2 \mathrm{~d}$ of culture, gonocytes remained mostly floating in the medium and gradually settled over the next $5 \mathrm{~d}$. Consequently, not changing the medium for $7 \mathrm{~d}$ (as opposed to changing it every $2 \mathrm{~d}$ ) led to a significant increase in the number of gonocyte colonies by reducing the loss of "floating gonocytes".

Conclusion: We found that gonocytes require the presence of a critical minimum number of somatic cells for settlement, and can proliferate and form growing colonies even in a basic medium. Large numbers of viable gonocytes remain floating in the medium for several days. The optimized culture conditions in the present study included seeding with $3.0 \times 10^{4}$ testis cells $/ \mathrm{cm}^{2}$ containing $\sim 40 \%$ gonocytes, incubating at $37{ }^{\circ} \mathrm{C}$, and without changing the medium in the first week, which can result in improved colony formation of porcine gonocytes.
\end{abstract}

Keywords: Cell culture, Male Germline stem cells, Pigs, Testis

\section{Background}

Testis stem cells are a unique population of stem cells in an adult body, because in addition to their dual ability to self-renew and give rise to differentiating germ cells, they can pass the genetic information to the offspring. Among the many types of male germ cells present from the fetal period to adulthood, primordial germ cells (PGCs), gonocytes, and particularly spermatogonial stem cells (SSCs) are believed to possess stem cell potential and hence are referred to as male germline stem cells (MGSCs) [1]. An in vivo functional assay for confirming the stem cell potential of MGSCs was provided when

\footnotetext{
*Correspondence: ali.honaramooz@usask.ca

Department of Veterinary Biomedical Sciences, Western College of Veterinary

Medicine, University of Saskatchewan, 52 Campus Drive, Saskatoon, SK S7N 5B4, Canada
}

SSCs were deposited in the lumen of seminiferous tubules of recipient testes using germ cell transplantation technique. The transplanted SSCs were capable of homing to the tubule basement membrane, forming new colonies of developing germ cells, and initiating donor-derived spermatogenesis [2-7]. In breeding trials, some of the germ cell recipient animals of various species were capable of siring donor-derived progeny $[2,6,8]$. There are also a few reports of using gonocytes and PGCs as donor cells in germ cell transplantation leading to the establishment of spermatogenesis in the recipient testis $[3,9,10]$.

The choice of donor MGSCs is a critical factor for the outcome of germ cell transplantation. Using PGCs as donor cells has been less practical because their isolation requires collection from embryos and there are only a limited number of PGCs per embryo [3, 11]. Spermatogonia

\section{Biomed Central}

(c) The Author(s). 2018 Open Access This article is distributed under the terms of the Creative Commons Attribution 4.0 International License (http://creativecommons.org/licenses/by/4.0/), which permits unrestricted use, distribution, and reproduction in any medium, provided you give appropriate credit to the original author(s) and the source, provide a link to the Creative Commons license, and indicate if changes were made. The Creative Commons Public Domain Dedication waiver (http://creativecommons.org/publicdomain/zero/1.0/) applies to the data made available in this article, unless otherwise stated. 
can be collected from mature donor individuals and enriched for SSCs at relatively high numbers. However, spermatogonia are inherently a heterogeneous population of cells and the lack of biomarkers that allow unequivocal isolation of SSCs has hampered obtaining pure populations [12-14]. Compared with PGCs and SSCs, gonocytes offer a potentially more practical option. Gonocytes are transitory germ cells (between PGCs and SSCs) that have a distinct morphology (large round cells with large nucleus to cytoplasm ratio), and are present during both fetal and early postnatal period for several days, months or even years, depending on the species [15-17]. Perhaps more importantly, gonocytes are the only germ cells present in the testes of neonates; thus, they can be detected using most germ cell markers (e.g., VASA, DAZL), pluripotency markers (e.g., NANOG, OCT4), and certain surface protein markers (e.g., DBA, UCH-L1). These characteristics provide an opportunity for enrichment and in vitro manipulation of gonocytes [17-20].

Gonocytes are relatively limited in numbers since they comprise only $\sim 1.4 \%$ of cells in the testes of neonatal rats [21] and $\sim 7 \%$ of seminiferous cord cells in piglets [22]. The efficiency of colonization by the donor germ cells in the seminiferous tubules of recipients is directly proportional to the number of transplanted MGSCs. Therefore, to increase the efficiency of germ cell transplantation, gonocytes must be enriched and/or propagated in vitro prior to transplantation, as suggested for SSCs [23, 24]. Various strategies have been introduced to optimize the isolation, enrichment, or purification of gonocytes with differing outcomes, depending on the species [18, 25, 26]. Using conventional cell separation methods, no more than $\sim 10 \%$ of isolated neonatal testis cells were gonocytes [21, 22, 27, 28]. However, development of a three-step enzymatic digestion in our laboratory has allowed the collection of populations of cells containing 40\% gonocytes from neonatal porcine testes [29]. The resultant population of gonocytes can also be enriched further to $\sim 90 \%$ using a combination of Nycodenz centrifugation and differential plating [30].

While pigs are an important biomedical animal model, purification of porcine MGSCs is still limited. The ability to obtain highly enriched populations of gonocytes from neonatal piglets $[29,30]$, however, has provided new opportunities for using gonocytes as a model for in vitro propagation and manipulation of MGSCs. This calls for further research on culture systems that can allow efficient large-scale propagation of gonocytes. No systematic study has examined the effects of different culture conditions on colony formation of porcine gonocytes. Therefore, given the importance of cell culture in MGSC research, the present study was designed to examine a number of culture conditions for maintenance, proliferation, and colony formation of neonatal porcine gonocytes as a model. In the present study, we performed six experiments in a stepwise design and examined several aspects of testis cell culture including factors related to the seeding density, gonocyte proportion, incubation conditions, sampling, medium changing regimens, and effects of applying those optimal conditions on gonocyte colony formation.

\section{Methods}

\section{Testis collection and preparation}

Testes from Yorkshire-cross piglets (Camborough-22 $\times$ Line 65; PIC Canada, Winnipeg, MB, Canada) less than 1 wk. of age were used in this study. The testes were collected weekly (5-15 pairs per week) through aseptic castration at a university-affiliated swine facility. The testes were kept in ice-cold Dulbecco's phosphate-buffered saline (DPBS; catalogue no. 20-031-CV; Mediatech, Manassas, VA, USA), containing $1 \% \mathrm{w} / \mathrm{v}$ antibiotics solution (penicillin and streptomycin; catalogue no. 30-002-CI, Mediatech), and were transported within $1 \mathrm{~h}$ of collection to the laboratory. The testes were thoroughly rinsed three times with DPBS prior to processing. The parenchyma was separated from the tunica albuginea and excess connective tissues, and used for isolation of testis cells.

\section{Isolation of testis cells and enrichment for gonocytes}

Isolation of testis cells and enrichment of gonocytes were performed using methods that were established in our laboratory (three-step enzymatic digestion, Nycodenz density gradient centrifugation and extracellular matrix (ECM) differential plating; [29, 30]). Briefly, for each batch of the three-step enzymatic digestion, $\sim 600 \mathrm{mg}$ of testis parenchyma was thoroughly minced with fine scissors for $5 \mathrm{~min}$, suspended in $5 \mathrm{~mL}$ of DPBS, vortexed for $30 \mathrm{~s}$ in a test tube shaker (Reax Top; catalogue no. 541-10000; Heidolph Instrument, Essex, UK) and digested with $1 \mathrm{~mL}$ of $0.2 \% \mathrm{w} / \mathrm{v}$ collagenase IV (catalogue no. C-153; SigmaAldrich, Oakville, ON, Canada), $0.1 \%$ w/v hyaluronidase (catalogue no. H-3884; Sigma-Aldrich), and 0.01\% DNase (catalogue no. DN25; Sigma-Aldrich) in Dulbecco's modified Eagle's medium (DMEM; catalogue no. 10-013-CM; Mediatech) supplemented with $1 \% \mathrm{w} / \mathrm{v}$ antibiotics (as above) at $37^{\circ} \mathrm{C}$ for $10 \mathrm{~min}$. Fetal bovine serum (FBS; catalogue no. A15-701; PAA Laboratories, Etobicoke, ON, Canada) was added to stop the digestion and the suspension was vortexed for another $30 \mathrm{~s}$ and filtered through a 40- $\mu \mathrm{m}$ filter (catalogue no. 3522340; BD Biosciences, San Jose, CA, USA). The filtrate suspension was centrifuged at $500 \times g$ at $16{ }^{\circ} \mathrm{C}$ for $5 \mathrm{~min}$ and resuspended in $5 \mathrm{~mL}$ of DPBS supplemented with $1 \% \mathrm{w} / \mathrm{v}$ antibiotics. Erythrocyte depletion was performed by mixing the cells with $20 \mathrm{~mL}$ of the lysis buffer, composed of $156 \mathrm{mmol} / \mathrm{L}$ ammonium chloride $\left(\mathrm{NH}_{4} \mathrm{Cl}\right.$; catalogue no. A9434; Sigma-Aldrich), $10 \mathrm{mmol} / \mathrm{L}$ potassium bicarbonate $\left(\mathrm{KHCO}_{3}\right.$; catalogue no. 237205; Sigma-Aldrich), and $0.1 \mathrm{mmol} / \mathrm{L}$ disodium 
ethylenediaminetetraacetate $\left(\mathrm{Na}_{2}\right.$ EDTA; catalogue no. E6635; Sigma-Aldrich) in sterile distilled water prior to another cycle of centrifugation $\left(500 \times g\right.$ at $16{ }^{\circ} \mathrm{C}$ for $\left.5 \mathrm{~min}\right)$. Finally, the cell pellet was resuspended in $5 \mathrm{~mL}$ of DMEM supplemented with $10 \% \mathrm{v} / \mathrm{v}$ FBS and $1 \%$ antibiotics $\left(\mathrm{DMEM}^{++}\right)$and underwent gentle pipetting to obtain a single cell suspension.

For enrichment of gonocytes among the cells obtained from the three-step enzymatic digestion, $3 \mathrm{~mL}$ of $17 \%$ Nycodenz in DPBS (Histodenz; catalogue no. D2158; Sigma-Aldrich) was placed at the bottom of a $15-\mathrm{mL}$ graduated conical tube. This was followed by gentle addition of $2 \mathrm{~mL}$ of cell suspension on top and the tube was centrifuged at $500 \times g$ at $4{ }^{\circ} \mathrm{C}$ for $15 \mathrm{~min}$. The supernatant was discarded and the pellet was harvested and resuspended as a single cell suspension. Prior to ECM differential plating, 6-well culture plates (catalogue no. 353046; BD Biosciences) were coated with $1 \mathrm{~mL}$ of $50 \mu \mathrm{g} / \mathrm{mL}$ poly-D-lysine (catalogue no. 47743-736; VWR International, Mississauga, ON, Canada) and $10 \mu \mathrm{g} / \mathrm{mL}$ fibronectin (catalogue no. 477743-728; VWR) in an incubator with $5 \% \mathrm{CO}_{2}$ at $37{ }^{\circ} \mathrm{C}$ for $1 \mathrm{~h}$, and dried in a biosafety cabinet for another $1 \mathrm{~h}$. The poly-D-lysine precoated wells were rinsed twice with DPBS before seeding the cells obtained from Nycodenz gradient density centrifugation. The cells were seeded onto the plates at a concentration of $2.5 \times 10^{5}$ cells $/ \mathrm{cm}^{2}$ in $\mathrm{DMEM}^{++}$, and cultured in an incubator with $5 \% \mathrm{CO}_{2}$ at $37{ }^{\circ} \mathrm{C}$. After 2 to $3 \mathrm{~h}$, the floating cells were harvested, centrifuged at $500 \times g$ at $16{ }^{\circ} \mathrm{C}$ for $5 \mathrm{~min}$ and the pellets were collected and resuspended as a single cell suspension. These procedures lead to obtaining isolated testis cells highly enriched in gonocytes. We performed a side-by-side quantitative comparison of the cell yield, viability and loss after each progressive step. Samples were prepared from single cell suspensions obtained from each step. The suspension was smeared onto poly-L-lysine precoated glass coverslips, dried overnight in a biosafety cabinet and kept at $-20{ }^{\circ} \mathrm{C}$ for use in immunostaining.

\section{Cell quantification and viability assessment}

The number of resultant cells after each isolation and enrichment step as well as after culturing was quantified, and the cell viability was assessed using the trypan blue exclusion technique. For evaluation of cells collected after isolation and enrichment, single cell suspensions were prepared as described above. For cultured cells, detachment of the adherent cells was performed by adding $1 \mathrm{~mL}$ of $0.25 \%(\mathrm{w} / \mathrm{v})$ trypsin in Hank's balanced salt solution (HBSS) and $2.21 \mathrm{mmol} / \mathrm{L}$ EDTA (catalogue no. 25-053CI; Mediatech) at $37{ }^{\circ} \mathrm{C}$ for 1-2 min (depending on confluency) with gentle agitation. The enzymatic digestion was stopped by adding $1 \mathrm{~mL}$ of undiluted FBS, and the mixture was centrifuged at $500 \times g$ at $16{ }^{\circ} \mathrm{C}$ for $5 \mathrm{~min}$. The pellets were collected and subjected to resuspension into a single cell suspension prior to assessment. Trypan blue (100 $\mu \mathrm{L}$ of a $0.4 \%$ solution in saline, catalogue no. T8154; Sigma-Aldrich) was mixed (1:1 ratio) gently with the cell suspension, and $20 \mu \mathrm{L}$ of the mixture was transferred to each hemocytometer chamber and live/dead cells were identified with the aid of a light microscope. For each replicate, two counts of live/dead cells were performed and averaged to calculate the yield and viability of cells (given as a percentage). Immunostaining was performed to confirm and quantify gonocytes, as they are the only type of germ cells present in neonatal pig testes; hence the remaining cells were categorized as somatic cells. For immunostaining, a minimum of 600 cells in randomly selected fields were counted in each cell smear and the proportion (\%) of gonocytes/somatic cells was calculated.

\section{Cell culture}

Different cell culture conditions were evaluated using a stepwise approach. The same medium $\left(\mathrm{DMEM}^{++}\right)$, culture plates (6-well plates), and incubator conditions (5\% $\mathrm{CO}_{2}$ and $95 \%$ humidity) were used in all experiments in order to evaluate the effects of changing other variables (i.e., gonocyte proportion, incubation temperature, cell seeding density, and medium changing regimen). For all experiments, $\mathrm{pH}$ of the medium was adjusted to $7.4 \mathrm{im}$ mediately prior to using it in cell cultures. The $\mathrm{pH}$ of the medium was measured using a digital $\mathrm{pH}$ meter (catalogue no. 11288-368; model Symphony SB70P; VWR). Cell growth was monitored at least once daily using an inverted phase contrast microscope (Nikon, Eclipse TS100). For each experiment, multiple replications were performed where cells obtained from each batch of testis tissue digestion were considered one replication. We have previously shown that the characteristics of cells obtained from 1-week old piglets from this source remain consistent over time, both within and among litters [29].

Effects of several factors on the behavior and the morphology of cultured testis cells were examined using cytology and immunostaining. The examined factors included different gonocyte proportions obtained before or after each step of enrichment ( $40 \%$ vs. $80 \%$ vs. $90 \%$ ), incubation temperature $\left(35{ }^{\circ} \mathrm{C}\right.$ vs. $\left.37{ }^{\circ} \mathrm{C}\right)$, cell seeding density $\left(1.0 \times 10^{5}\right.$ vs. $3.0 \times 10^{5}$ vs. $5.0 \times 10^{5}$ cells/well; each well in a 6-well plate has $\sim 10 \mathrm{~cm}^{2}$ cell growth area) and medium changing regimen (every $2 \mathrm{~d}$ vs. modified regimen vs. no changing of medium for up to $7 \mathrm{~d}$ ). Confluency assessment was defined as the relative coverage of the plate surface by the mixture of testis cells, and a gonocyte colony was defined as a group of more than three gonocytes in close contact. 


\section{Sampling}

For sampling, glass coverslips coated with $0.1 \% \mathrm{w} / \mathrm{v}$ polyL-lysine were used. Glass coverslips sized $22 \times 22 \mathrm{~mm}$ (catalogue no. 12-540B; Fisher Scientific, USA) were arranged in a sterile metal coverslip rack and immersed in $1 \% \mathrm{HCl}$ in $70 \%$ alcohol for $10 \mathrm{~min}$, followed by rinsing with sterile distilled water for $5 \mathrm{~s}$ and allowed to dry for $20 \mathrm{~min}$. The rack was transferred into a $0.1 \% \mathrm{w} / \mathrm{v}$ poly-Llysine (catalogue no. P8920; Sigma-Aldrich) solution for $10 \mathrm{~min}$ and allowed to dry overnight. Finally, the glass coverslips were placed at the bottom of each well in 6-well plates. These procedures were conducted under a biosafety cabinet.

\section{Immunostaining}

Gonocytes were identified by immunostaining using Dolichos biflorus agglutinin (DBA) according to previously described protocols $[29,30]$, with minor modifications. Briefly, the dried coverslips (with cell smears or with cells grown directly on them) were fixed in Bouin's solution (catalogue no. 1120-31; Richa Chemical Company, Pocomoke City, MD, USA) for 2$3 \mathrm{~min}$. The samples were then rinsed three times with $70 \%$ alcohol to remove excess Bouin's solution followed by three rinses with DPBS. The samples were blocked with $5 \%$ bovine serum albumin (BSA; catalogue no. 0332, Amresco, Solon, OH, USA) at $37{ }^{\circ} \mathrm{C}$ for $30 \mathrm{~min}$ in a humidified chamber. The blocking agent was removed and the samples were incubated with fluorescein-conjugated lectin DBA (1:100, catalogue no. FL-1031, Vector Labs, Burlington, ON, Canada) overnight at $4{ }^{\circ} \mathrm{C}$ in a humidified chamber. The samples underwent another cycle of rinsing, followed by incubation with $0.3 \%$ Sudan Black $\mathrm{B}$ w/v (catalogue no. S2380; Sigma-Aldrich) in 70\% alcohol for $15 \mathrm{~min}$, at $37{ }^{\circ} \mathrm{C}$ in a humidified chamber. The samples were rinsed with DPBS and stained with 4'6'-diamidino-2-phenyilindole (DAPI; catalogue no. D9542; Sigma-Aldrich) and observed under a fluorescence microscope. Fluorescein-conjugated lectin DBA specifically labels gonocytes which appear green under the fluorescence microscope while DAPI stains the nuclei of all cells which appear blue (Fig. 1).

\section{Statistical analyses}

Unless stated otherwise, all data are presented as means \pm standard error of mean (SEM) and analyzed using either one-way or two-way analysis of variance (ANOVA), as appropriate, followed by Tukey's HSD post-hoc test. For percentages, the data were transformed using
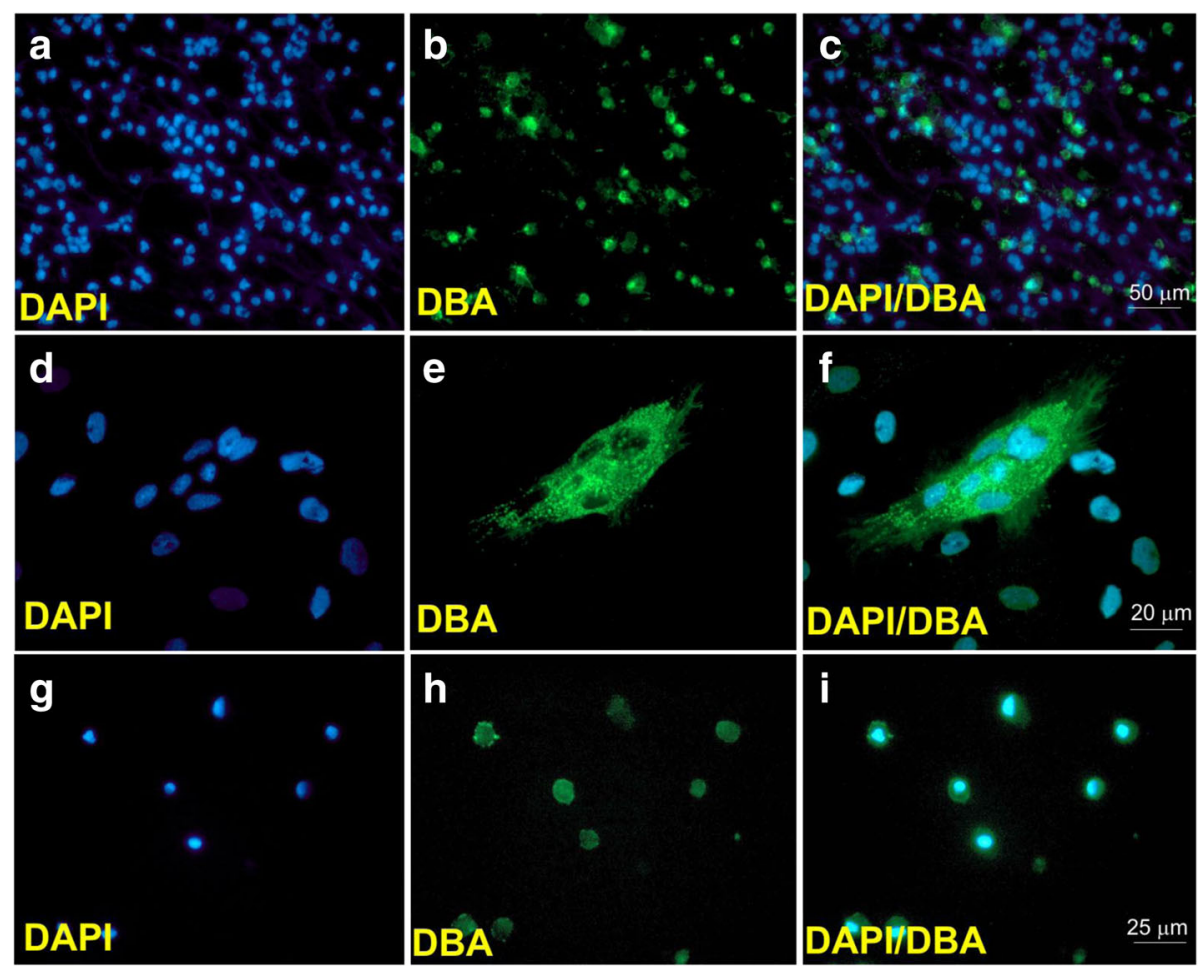

Fig. 1 Dolichos biflorus agglutinin (DBA) immunostaining of neonatal gonocytes. a-c Gonocyte immunostaining performed on testis cell smears collected immediately following cell isolation. $\mathbf{d}$-f Multiple gonocytes form a colony on a somatic-cell monolayer observed at 1 wk of culture. $\mathbf{g}$-i Floating gonocytes in the removed medium observed $4 \mathrm{~d}$ after incubation. $\mathbf{b}, \mathbf{e}, \mathbf{h}$ Fluorescein-conjugated DBA-labeled gonocytes appear green under the fluorescence microscope. $\mathbf{a}, \mathbf{d}, \mathbf{g}$ DAPI-stained nuclei of the cells appear blue. $\mathbf{c}, \mathbf{f}, \mathbf{i}$ Merged images 
Arcsine function prior to analysis using ANOVA. The level of significance was set at $P<0.05$. Data were analyzed using SPSS (Version 20.0; SPSS, Chicago, IL, USA).

\section{Results}

As summarized in Table 1, enzymatic digestion of testis tissues yielded a population of testis cells containing 41\% germ cells (Fig. 1a-c), which at this developmental stage $(\sim 1 \mathrm{wk}$ of age) are exclusively gonocytes. Gradient centrifugation by Nycodenz, followed by ECM differential plating resulted in enrichment of gonocytes to $\sim 80 \%$ and $\sim 86 \%$, respectively. However, the enrichment procedures also caused significant reductions $(P<0.05)$ in cell counts after each step, resulting in $\sim 73 \%$ and $\sim 92 \%$ total testis cell loss and $\sim 47 \%$ and $\sim 83 \%$ gonocyte loss, respectively. The relatively lower gonocyte loss at each step, compared with the total cell loss, resulted in significant enrichment of gonocytes. The viability of cells was also reduced after each enrichment step (from $\sim 93 \%$ to $84 \%$ and $82 \%$, respectively, $P<0.05)$. When the cells were cultured $\left(3.0 \times 10^{5}\right.$ cells/ well at $37{ }^{\circ} \mathrm{C}$ with $5 \% \mathrm{CO}_{2}$ and the medium was changed every $2 \mathrm{~d}$ ), only the cells used immediately after the threestep enzymatic digestion (i.e., without enrichment) demonstrated growth by reaching $\sim 90 \%$ confluency in $\sim 6 \mathrm{~d}$.

\section{Exp. 1: Effect of cell seeding density and gonocyte proportion}

One of the objectives of this experiment was to determine the optimal seeding density for culturing testis cells. A comparison was made by randomly assigning cells into 6-well plates at $1.0 \times 10^{5}, 3.0 \times 10^{5}$, or $5.0 \times$ $10^{5}$ cells/well (i.e., $1.0 \times 10^{4}, 3.0 \times 10^{4}$, or $5.0 \times 10^{4}$ cells $/ \mathrm{cm}^{2}$ since each well was $\sim 10 \mathrm{~cm}^{2}, n=12$ replications), in $3 \mathrm{~mL}$ of medium to determine the time required for the cells to reach $90 \%$ confluency. Cells were used fresh (immediately after enzymatic digestion and without enrichment, hence containing 40\% gonocytes) and cultured under similar conditions at $37{ }^{\circ} \mathrm{C}$, and the medium was changed every $2 \mathrm{~d}$.

As shown in Table 2, cells in the highest seeding density group $\left(5.0 \times 10^{5}\right)$ became confluent earlier than other groups $(P<0.05)$, reaching $>90 \%$ confluency in $\sim 4 \mathrm{~d}$, while the $3.0 \times 10^{5}$ seeding density group of cells were $>90 \%$ confluent by $\sim$ Day 6 . Cells cultured at $1.0 \times 10^{5}$ seeding density had slow growth and only reached $\sim 30 \%$ confluency after $7 \mathrm{~d}$ in culture.

In a separate experiment, testis cells enriched for gonocytes (undergoing both Nycodenz centrifugation and ECM plating, hence containing $\sim 86 \%$ gonocytes) were used as the source of cells for culturing, using the same incubation conditions. Cells did not grow in plates seeded with $1.0 \times 10^{5}$ or $3.0 \times 10^{5}$ cells/well and only had limited growth in the $5.0 \times 10^{5}$ seeding density group after $7 \mathrm{~d}$ in culture (5-15\% confluency, data not shown). Therefore, for the remaining experiments in this study we used testis cells without enrichment (i.e., containing $\sim 40 \%$ gonocytes), and since the $3.0 \times 10^{5}$ seeding density resulted in confluency of cells in $\sim 6 \mathrm{~d}$ (without the need for passaging the cells within $1 \mathrm{wk}$ ), we used this seeding density in the subsequent experiments.

\section{Exp. 2: Effect of incubation temperature}

The objective of this experiment was to evaluate the growth of cultured testis cells using incubation temperatures of either $35^{\circ} \mathrm{C}$ or $37^{\circ} \mathrm{C}$ for 1 wk $(n=12$ replications), while other culture conditions remained the same (e.g., medium, cell seeding density, and $\mathrm{CO}_{2}$ levels). As shown in Table 3 , the viability and number of cells at confluency did not differ between the two incubation temperatures $(P>0.05)$. However, the cells cultured at $35{ }^{\circ} \mathrm{C}$ reached confluency later than those at $37{ }^{\circ} \mathrm{C}(P<$ 0.05 ); therefore, for practical reasons we chose to culture the cells at $37^{\circ} \mathrm{C}$ for subsequent experiments.

\section{Exp. 3: Sampling of cultured testis cells for analysis}

Various methods can be used to sample cultured cells for analysis. When sampling for applications such as immunocytochemistry, coverslips are commonly precoated with certain matrices to enhance adherence of cells. It is not clear whether the presence of the precoated coverslips in testis cell culture would affect cell growth. Furthermore, in situations where multiple samplings from each replicate is required, it would be more efficient to use all available cultured cells, including those grown on areas of the culture well not covered by

Table 1 The population of testis cells obtained after enzymatic digestion and subsequent enrichment

\begin{tabular}{|c|c|c|c|c|c|c|c|c|}
\hline \multirow[t]{2}{*}{ Method } & \multicolumn{2}{|l|}{ Proportion, \% } & \multicolumn{2}{|c|}{ Cell count, $\times 10^{6} *$} & \multicolumn{2}{|l|}{ Cell loss, \% ** } & \multirow[t]{2}{*}{ Viability, \% } & \multirow{2}{*}{$\begin{array}{l}\text { In vitro } \\
\text { growth }\end{array}$} \\
\hline & Gonocytes & Somatic cells & Total & Gonocytes & Total & Gonocytes & & \\
\hline Enzymatic digestion & $40.60 \pm 1.21^{\mathrm{a}}$ & $59.40 \pm 1.21^{a}$ & $37.84 \pm 2.44^{a}$ & $15.38 \pm 1.09^{a}$ & - & - & $92.62 \pm 0.59^{a}$ & Yes \\
\hline Nycodenz centrifugation & $80.40 \pm 1.46^{b}$ & $19.60 \pm 1.46^{b}$ & $10.00 \pm 0.41^{b}$ & $8.00 \pm 0.21^{b}$ & $73.18 \pm 1.76^{a}$ & $46.72 \pm 4.69^{a}$ & $84.20 \pm 1.06^{b}$ & \\
\hline ECM differential plating & $86.40 \pm 1.03^{c}$ & $13.60 \pm 1.03^{c}$ & $3.02 \pm 0.19^{c}$ & $2.60 \pm 0.2^{c}$ & $91.62 \pm 0.79^{b}$ & $82.61 \pm 1.71^{b}$ & $81.66 \pm 0.71^{c}$ & Бाтा \\
\hline
\end{tabular}

The results are mean \pm SEM

*Each replicate was based on the digestion of $\sim 600 \mathrm{mg}$ of testis tissue

One-way ANOVA (or $t$ test ${ }^{*}$ ) was used for statistical analyses, and $P<0.05$ was considered as significant

${ }^{\mathrm{abc}}$ Within each column, data with different superscripts differ significantly $(P<0.05) . n=5$ replications 
Table 2 The effect of seeding density on the growth of testis cells in culture

\begin{tabular}{llll}
\hline $\begin{array}{l}\text { Cell } \\
\text { seeding } \\
\text { density }\end{array}$ & Maximum confluency & & \\
\cline { 2 - 4 } & Confluency at days & Cell count & Viability, \% \\
\hline $1.0 \times 10^{5}$ & $\left({ }^{*} \sim 30 \%\right.$ at 7$)$ & $\left({ }^{*} 2.98 \times 10^{5} \pm 0.01\right)$ & $\left({ }^{*} 88.4 \pm 1.02\right)$ \\
$3.0 \times 10^{5}$ & $>90 \%$ at $6.0 \pm 0.17^{\text {a }}$ & $8.10 \times 10^{5} \pm 0.01$ & $91.21 \pm 0.58$ \\
$5.0 \times 10^{6}$ & $>90 \%$ at $4.0 \pm 0.15^{\text {b }}$ & $8.16 \times 10^{5} \pm 0.01$ & $91.62 \pm 0.56$ \\
\hline
\end{tabular}

The results are mean \pm SEM

*The results from $1.0 \times 10^{5}$ seeding density group were excluded from statistical analysis as the cells did not reach $90 \%$ confluency Independent sample $t$ test was used for statistical analyses

${ }^{\mathrm{ab}}$ Within each column, data with different superscripts differ significantly $(P<$ 0.05). $n=12$ replications

the coverslip. The objectives of this experiment were to determine 1) whether the rate or pattern of testis cell growth in culture would change in the presence of glass coverslips $(22 \times 22 \mathrm{~mm})$ coated with $0.01 \%$ poly-L-lysine, and 2) whether the growth of testis cells on the coverslips differs from those on the peripheral areas of the wells, not covered by the coverslips (Fig. 2).

When plates with and without poly-L-lysine-coated coverslips were compared, the number or viability of the resultant cultured cells did not differ between plates $\left(8.18 \pm 0.01 \times 10^{5}\right.$ vs. $8.22 \pm 0.02 \times 10^{5}$ cells per plate, with $91.0 \pm 0.57 \%$ vs. $91.3 \pm 0.87 \%$ cell viability, plates with coverslips vs. plates with no coverslips, respectively, $n=12$ replications, $P>0.05$ ). When non-coated coverslips were used, little or no cell growth was observed. Furthermore, within the plates with poly-L-lysine-coated coverslips, the viability of cells grown on coverslips did not differ from those grown on the peripheral areas of the well, not covered by the coverslips $(92.0 \pm 0.33 \%$ vs. $92.4 \pm 0.51 \%$, coverslips vs. periphery, respectively, $P>$ $0.05)$. However, the number of cells obtained from the peripheral areas was higher than that from the coverslips $\left(4.59 \pm 0.14 \times 10^{5}\right.$ vs. $2.99 \pm 0.06 \times 10^{5}$, respectively, $P<$ $0.05)$, even though both encompassed a similar cell growth area $\left(\sim 4.8 \mathrm{~cm}^{2}\right.$ each).

Exp. 4: Short-term culture of neonatal porcine testis cells Morphological changes of neonatal porcine testis cells in culture were evaluated for 1 wk under the above-

Table 3 The effect of incubation temperature on the growth of testis cells in culture

\begin{tabular}{llll}
\hline Temperature & \multicolumn{2}{l}{$>90 \%$ confluency } & \\
\cline { 2 - 4 } & Days & Cell count & Viability, \% \\
\hline $35^{\circ} \mathrm{C}$ & $6.42 \pm 0.15^{\mathrm{a}}$ & $7.98 \times 10^{5} \pm 0.01$ & $89.98 \pm 0.49$ \\
$37^{\circ} \mathrm{C}$ & $5.83 \pm 0.17^{\mathrm{b}}$ & $8.27 \times 10^{5} \pm 0.01$ & $90.04 \pm 0.49$
\end{tabular}

The results are mean \pm SEM

Independent sample $t$ test was used for statistical analyses

${ }^{a b}$ Within each column, data with different superscripts differ significantly $(P<$ 0.05). $n=12$ replications mentioned culture conditions $\left(3.0 \times 10^{5}\right.$ seeding density, DMEM $^{++}, 37{ }^{\circ} \mathrm{C}, n=6$ replications). The medium was changed every $2 \mathrm{~d}$. Within the first $12 \mathrm{~h}$ of incubation, most of the cells and cell particles were still floating in the medium (Fig. 3a). By $24 \mathrm{~h}$ after incubation, small numbers of cells settled and appeared to have adhered to the plate. The early settling cells were mostly somatic cells and began to form cytoplasmic projections, creating irregularly shaped cell boundaries (Fig. 3b), while more cells continued to settle. After $2 \mathrm{~d}$ of incubation, the cells started to appear in clumps (Fig. 3c), and over time these groups of cells spread further and combined to create a large somatic-cell monolayer. At the same time, round cells with large nuclei, appearing bright or with a halo under the phase-contrast microscopy, were seen attached onto the somatic-cell monolayer (Fig. 3d-e). These rounds cells were confirmed to be gonocytes using immunostaining (Fig. 1d-f). It was also observed that while initially gonocytes were present as singles or pairs, starting at Day 5, colonies (grape-like clumps) of more than 3 cells could also be observed (Fig. 3d). It was noticed that gonocytes were only loosely attached to the somatic-cell monolayer, since some would detach due to slight movements of the plate. By the end of the experiment (Day 7), the number of these round cell colonies were still considerably less than expected, given that the population of testis cells at seeding contained $\sim 41 \%$ gonocytes. The somatic cells continued to multiply and once reaching $70-80 \%$ confluency (at $\sim 4$ to $5 \mathrm{~d}$ ), many appeared as spindle-shaped fibroblast-like cells (Fig. 3e).

\section{Exp. 5: Floating cells in the culture medium}

Based on the findings of Exps. 1 and 4, it was clear that gonocytes require sufficient ratios of somatic cells or feeder cells, to which they formed loose attachment for growth in culture. We speculated that the very low number of gonocyte colonies observed by Day 7 during short-term culture (Fig. 3e) might be due to their loss through routine medium changes, which apparently eliminated the floating and loosely adherent gonocytes. Therefore, this experiment was designed to examine the medium removed from the plates. The results showed that indeed high numbers of round cells were present in the medium removed routinely every other day. The number of these cells was greatest in the medium removed on Day $2\left(6.81 \pm 0.63 \times 10^{4}\right)$, compared with Days 4 and $6\left(1.02 \pm 0.09 \times 10^{4}\right.$ and $0.4 \pm 0.07 \times 10^{4}$ cells/well, $P<0.05, n=5$ replications, Fig. 4$)$. On the other hand, if the medium was not changed, greater numbers of floating gonocytes remained in the medium examined on Days 4 and $6\left(4.2 \pm 0.10 \times 10^{4}\right.$ and $1.92 \pm 0.05 \times 10^{4}$ cells/ well, respectively), compared with the numbers obtained on the same days when the medium was changed every other day $(P<0.05, n=5$ replications, Fig. 4$)$. Based on 


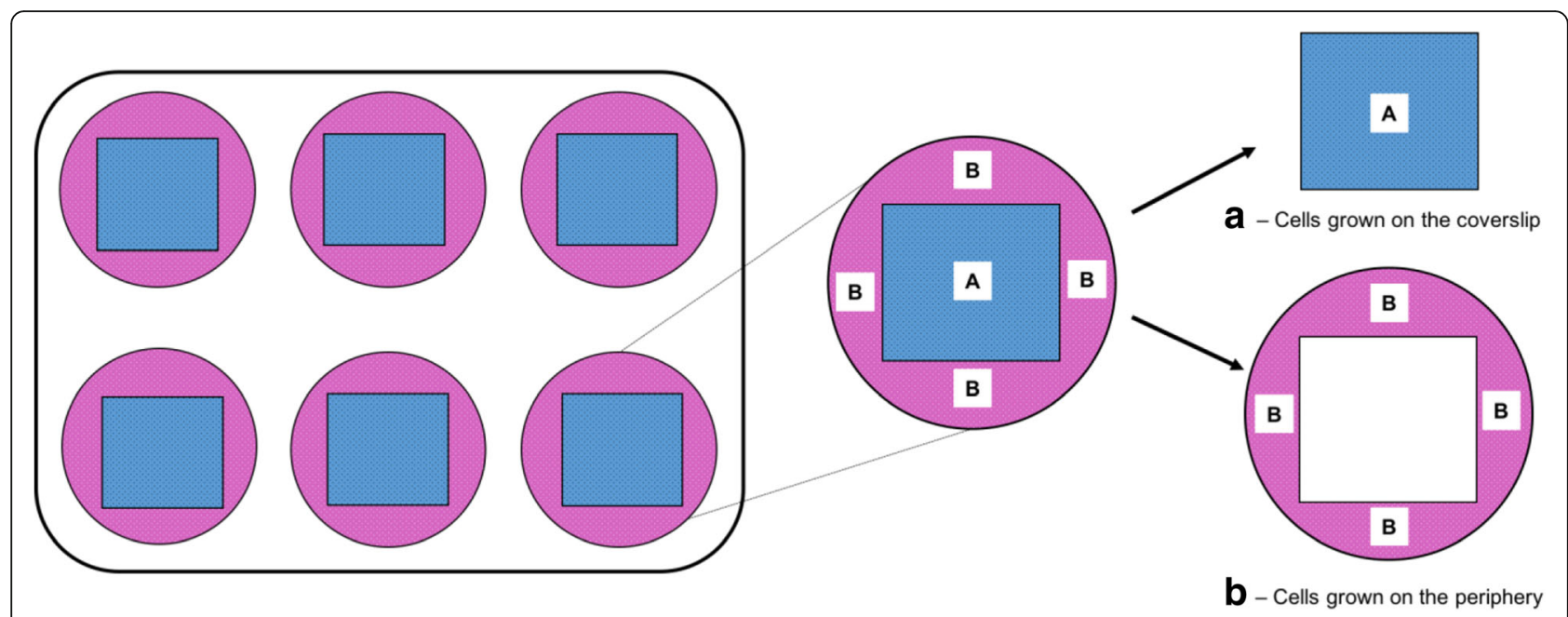

Fig. 2 Schematic representation of the areas within culture plates used for sampling in Exp. 3. The numbers and viability of cells grown on polyL-lysine-coated coverslips (a) were compared with those grown on the peripheral areas of the wells, not covered by the coverslip (b)

the morphology, it was presumed that these cells were gonocytes; they were large and round in shape with prominent nuclei (large nucleus to cytoplasm ratio). The viability of these round cells remained high in all examined days ( $85-97 \%$, data not shown). Using immunostaining, these round cells were later confirmed to be gonocytes (Fig. 1g-i).

\section{Exp. 6: Effect of medium changing regimens on attached gonocytes}

This experiment was designed to assess the effects of different medium changing regimens on the number and viability of attached gonocytes. The cells were cultured using the selected culture conditions $\left(3.0 \times 10^{5}\right.$ testis cells/well containing $\sim 40 \%$ gonocytes, $\mathrm{DMEM}^{++}, 37^{\circ} \mathrm{C}$ )
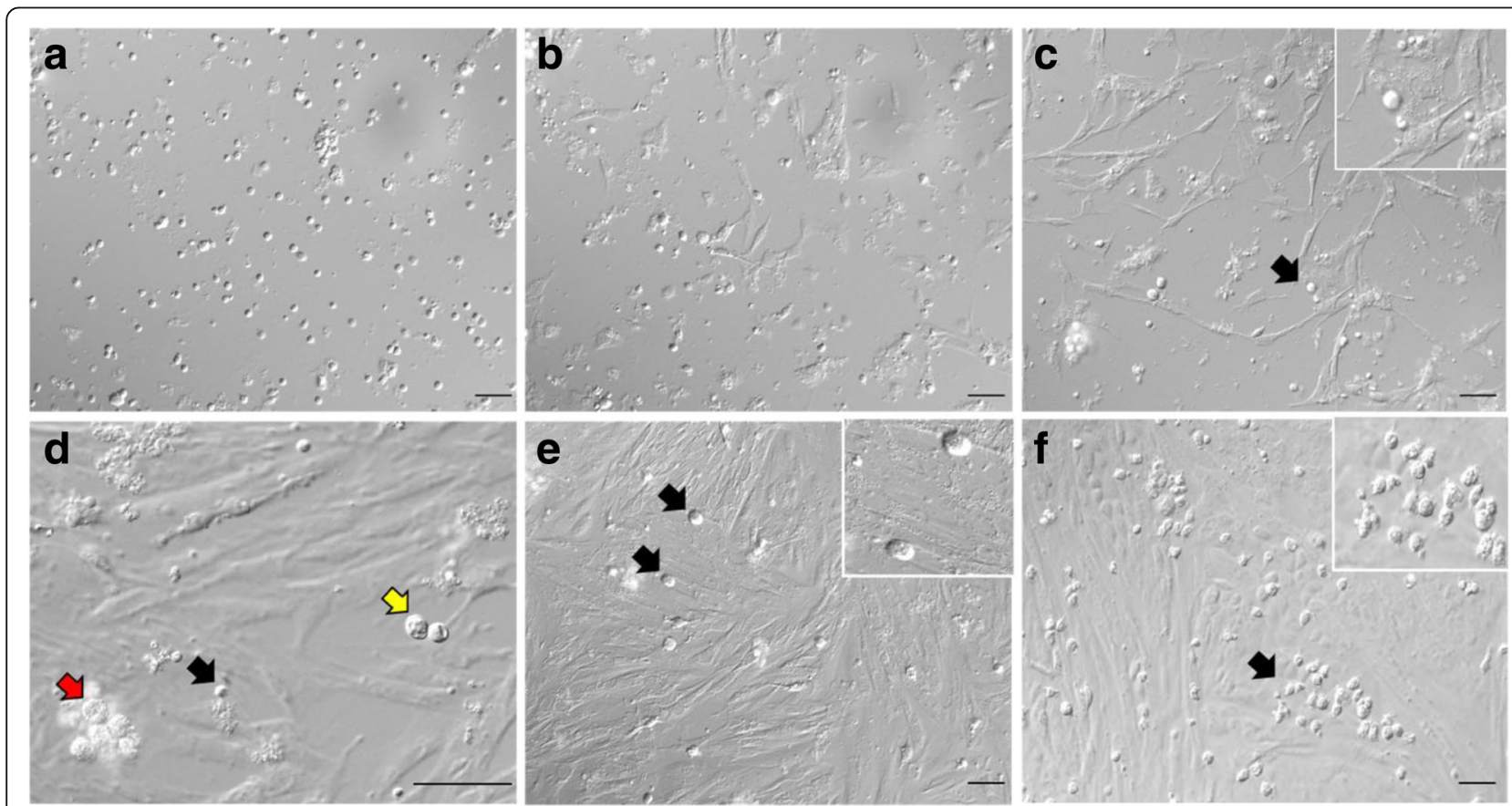

Fig. 3 Morphology of testis cells in short-term cell culture. a Morphology of floating cells $12 \mathrm{~h}$ after seeding. $\mathbf{b}$ Some somatic cells settled to the bottom of the plate within $24 \mathrm{~h}$ of incubation. c These somatic cells extended cytoplasmic projections toward one another. c-f Cells presumed to be gonocytes are seen attached to somatic cells (black arrows). The same gonocytes are also shown at a higher magnification (insets). $\mathbf{d}$ Gonocytes appeared as singles (black arrow), pairs (yellow arrow), or small colonies (red arrow). e Spindle-shaped fibroblast-like cells were more prominent when confluency reached $>70 \%$. Only a small number of gonocyte colonies were observed by Day 7 when routine medium changing regimen was applied. $\mathbf{f}$ Increased number of gonocyte colonies were observed when the medium was not changed for $7 \mathrm{~d}$. Scale bar, $50 \mu \mathrm{m}$ 


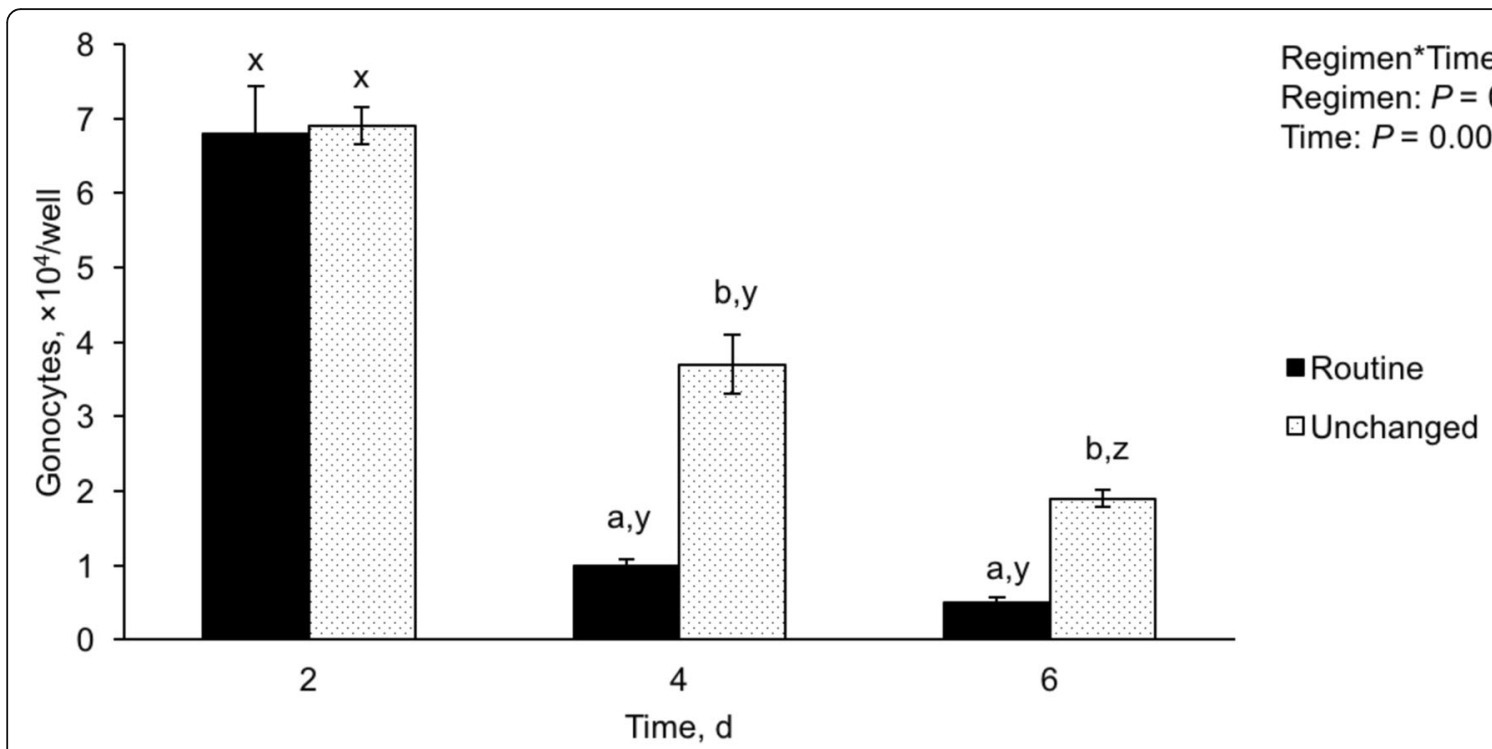

Fig. 4 Number of gonocytes upon analysis of the floating cells from the removed medium. The initial number of cells at seeding was set at $3.0 \times 10^{5}$ cells/well containing $\sim 40 \%$ gonocytes and the viability was $89 \pm 0.5 \%$. The medium removed from the plates was examined and large numbers of gonocytes were seen floating in the medium on Day 2. Most of the floating gonocytes were eliminated by routine (every $2 \mathrm{~d}$ ) medium changes (Routine), while some were present on Days 4 and 6 , if the medium was not changed (Unchanged). The data are mean \pm SEM. ${ }^{\text {ab }}$ Data with different superscripts within each day differ significantly $(P<0.05) .{ }^{x y z}$ Data with different superscripts within each treatment over time differ significantly $(P<0.05) . n=5$ replications

for $1 \mathrm{wk}$, and medium changing regimens were assigned to groups of plates as follows: 1) to serve as a control group, the cells were seeded with $3 \mathrm{~mL}$ of medium, and the medium was changed routinely, every $2 \mathrm{~d}$ (routine group, 3 changes in $1 \mathrm{wk}) ; 2$ ) the cells were seeded with $2 \mathrm{~mL}$ of medium, followed by the addition of another $1 \mathrm{~mL}$ after $24 \mathrm{~h}$, and then every $2 \mathrm{~d} 1 \mathrm{~mL}$ of medium was removed from the well and replaced with $1 \mathrm{~mL}$ of fresh medium (modified group); or 3 ) the cells were seeded with $3 \mathrm{~mL}$ of medium but the medium was not changed (unchanged group). On Days 2, 4, 6, and 7, the cultured cells were observed under an inverted microscope and the number of gonocyte colonies in four randomly selected fields at $400 \times$ was recorded and cells were collected for evaluation of viability $(n=5$ replications per group).

As shown in Fig. 5, alterations in medium changing regimens affected the number of attached gonocytes or gonocyte colonies present on the somatic-cell monolayers. Overall, the number of gonocyte colonies increased $(P<$ 0.05) from Day 2 to Day 4 of culture in all medium changing regimens. However, among the medium changing regimens, the unchanged group had greater $(P<0.05)$ number of gonocyte colonies on Days 6 and 7 compared with the routine medium changing group (control).

The viability of cells in different medium changing regimens is shown in Fig. 6. Compared with the cell viability at seeding ( $90 \%)$, there was a reduction in viability of cells at Days 4,6 , and 7 in all groups $(P<0.05)$. The cell viability was reduced further in the unchanged group on Days 6 and $7(P<0.05)$. Between the regimens, the viability of cells in the unchanged groups was lower $(P<0.05)$ than the routine group on Days 6 and 7 of culture.

\section{Discussion}

In the neonatal testis, gonocytes represent MGSCs, which have great potential applications in male reproduction research (reviewed in [31, 32]). Various methods have been established to culture MGSCs to facilitate their study and manipulation or to harness their potential for downstream applications such as genetic conservation, transgenesis, or infertility treatments $[4,5,33-35]$. However, depending on the donor species, age, or developmental status, optimized culturing or enrichment of MGSCs can be challenging [29, 36].

Cell isolation is a critical step in preparing testis cells for culture. The number and proportion of the resultant populations of cells also vary greatly depending on the methods used to isolate the cells. As a first step in the present study, we performed a side-by-side comparison of the total testis cell yield and gonocyte proportions from three protocols [29, 30]. Although as expected the enrichment process resulted in highly purified populations of gonocytes $(\sim 86 \%)$, it also led to losing up to $90 \%$ of the initial number of testis cells. These findings provide a basis upon which an appropriate approach could be adopted for gonocyte isolation/ enrichment in order to meet the objectives and needs of specific experiments. For example, the highly 


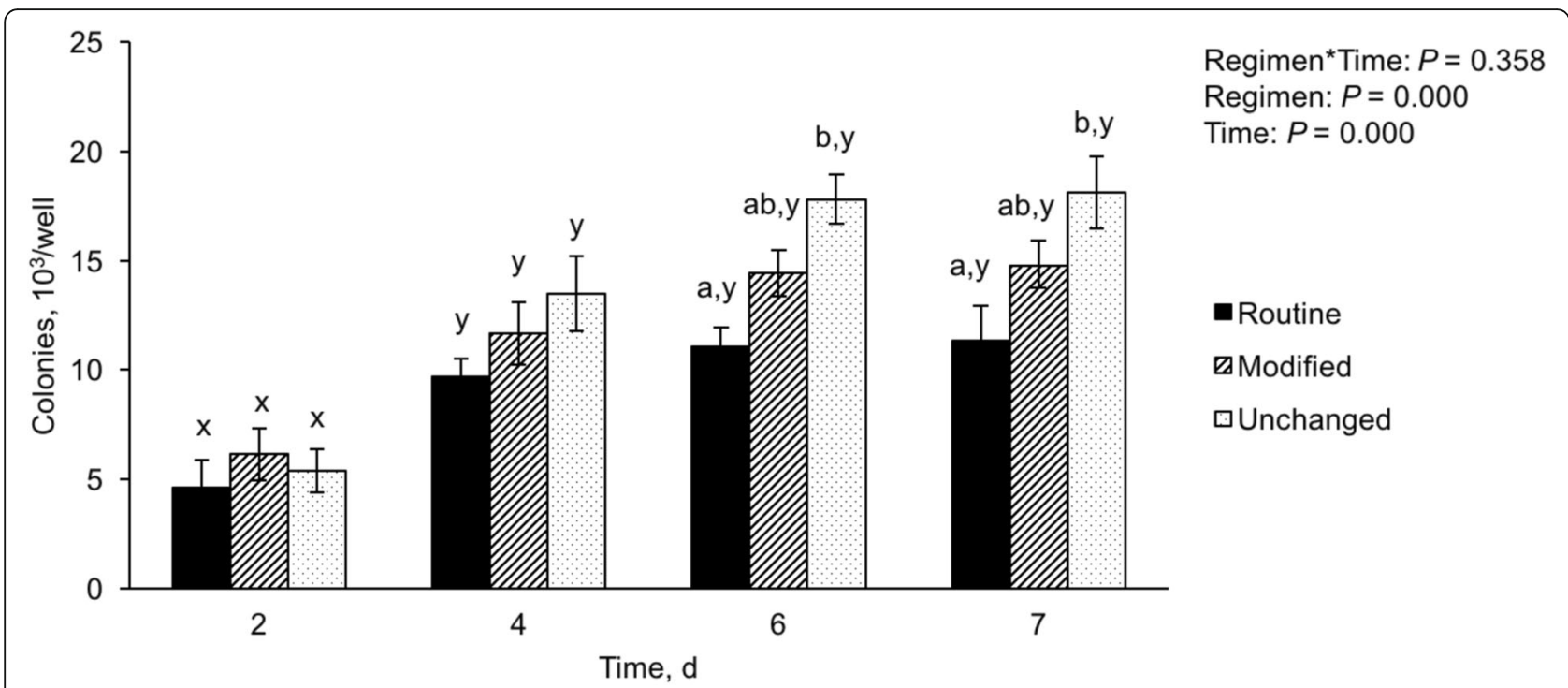

Fig. 5 Number of gonocytes or gonocyte colonies observed after applying different medium changing regimens. The cultured cells underwent one of the following medium changing regimens: 1) Seeded with $3 \mathrm{~mL}$ of medium and the medium was routinely changed every $2 \mathrm{~d}$ (Routine); 2) Seeded with $2 \mathrm{~mL}$ of medium, followed by the addition of another $1 \mathrm{~mL}$ after $24 \mathrm{~h}$, and then every $2 \mathrm{~d}, 1 \mathrm{~mL}$ of medium was removed from the well and replaced with $1 \mathrm{~mL}$ of fresh medium (Modified); 3) Seeded with $3 \mathrm{~mL}$ of medium but the medium was not changed for $7 \mathrm{~d}$ (Unchanged). The data are mean \pm SEM. ${ }^{\text {ab }}$ Data with different superscripts within each day differ significantly $(P<0.05)$. ${ }^{x y}$ Data with different superscripts within each treatment over time differ significantly $(P<0.05) . n=5$ replications

enriched populations of gonocytes could be used in studies that focus mainly on gonocytes per se, while the heterogeneous populations of testis cells obtained immediately after enzymatic digestion may be more suitable for longer term culture or for the study of interactions between gonocytes and somatic cells.

One of the advantages of using neonatal testes as the source of germ cells is that gonocytes are the only type of germ cells present during the early postnatal stage. Gonocytes possess a distinct morphology and a unique pattern of distribution in the seminiferous cords of neonatal testes, which facilitate their identification in situ $[18,21]$. Once the cells are enzymatically dissociated; however, accurate identification of gonocytes requires immunocytochemistry. There are several biomarkers that could be used for identification of gonocytes including germ cell markers (e.g., VASA and DAZL, $[37,38])$ and stem cell markers (e.g., Nanog, SSE-A1, and OCT4, $[18,20,39,40])$. Two of the most commonly used markers for neonatal porcine gonocytes are DBA [18, 19, 41] and ubiquitin C-terminal hydrolase L1 (UCH-L1; previously known as PGP9.5) [41, 42]. DBA has a specific affinity to bind to $\alpha$-D-N-acetyl-galactosamine, which is localized on the surface of porcine gonocytes (i.e., primitive germ cells) [18], while UCH-L1 can identify both primitive and more advanced germ cells.

In the present study, identification of gonocytes was initially hampered by autofluorescence, which was partly overcome by using a quenching protocol [19]; however, some autofluorescence remained. Autofluorescence in the tissue/ cells can be due to endogenous sources (e.g., lipofuscin or lipofuscin-like pigments), or acquired during processing (e.g., certain fixatives). In any case, autofluorescence can interfere with specific signals by immunostaining and lead to false positive results. In the present study, the autofluorescence was eliminated through modification of the quenching protocol [19]. The use of Sudan black B (SBB) has been reported to be efficient in masking autofluorescence of lipofuscins, triglycerides, and lipoproteins origin $[43,44]$ and is a major component of the quenching protocol for testis cells [19]. In this study, as a first step in modifying the original quenching protocol, the length of incubation with SBB was extended, which led to further reduction of the autofluorescence of testis cells, but not to its complete elimination. We then speculated that the remaining autofluorescence might have a fixative origin. The picric acid component of Bouin's solution used for fixing testis tissue has also been cited as a potential cause of autofluorescence $[45,46]$. Therefore, we applied further control measures to refine the use of fixatives in the quenching protocol. We found that inclusion of three thorough and gentle rinses with 70\% alcohol after the Bouin's fixation completely eliminated the autofluorescence problem in Bouin's fixed testis cell samples. As an alternative, we also found that to avoid the autofluorescence caused by Bouin's, cell smears or cells grown on coverslips can be fixed using methanol at $-20^{\circ} \mathrm{C}$ for $10 \mathrm{~min}$.

Cell seeding density influences the performance of cultured cells, presumably by affecting the contact and interactions among cells [47]. Optimization of the cell 


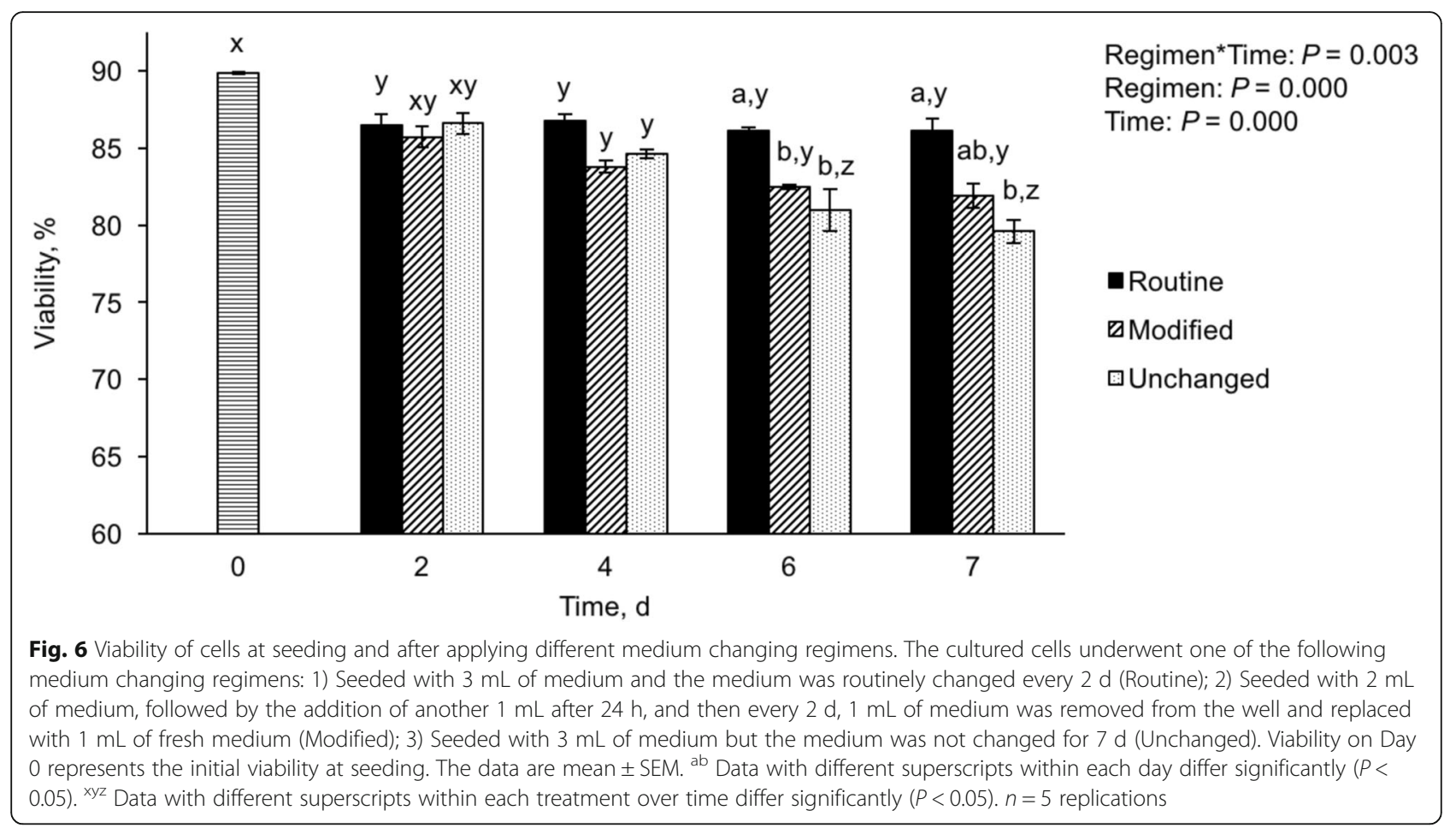

seeding density prior to culturing cells ensures normal cell growth and allows estimation of the time to reach certain confluency levels. In the present study, the cell seeding density of $3.0 \times 10^{5}$ /well (i.e., in $\sim 10 \mathrm{~cm}^{2}$ ) was found to be more practical because it allowed sampling within $1 \mathrm{wk}$. without a need for passaging the cells.

Temperature may play an important role in the efficiency of testis cell culture, but the effect of incubation temperature on proliferation of neonatal porcine testis cells has not been well studied. In Exp. 2, testis cells were cultured at either 35 or $37{ }^{\circ} \mathrm{C}$ to mimic the testis temperature in situ, which is normally lower than the core body temperature (range $38-40{ }^{\circ} \mathrm{C}$ in pigs $[48,49]$ ). Testis cells cultured at either 35 or $37{ }^{\circ} \mathrm{C}$ proliferated and reached a $90 \%$ confluency within 1 wk.; however, those cultured at $35{ }^{\circ} \mathrm{C}$ became $90 \%$ confluent later (5.8 vs. $6.4 \mathrm{~d}$, respectively, $P<0.05)$. Earlier studies using human or mouse testis cells concluded that DNA synthesis and steroidogenesis were increased when cells were cultured at $31 / 32{ }^{\circ} \mathrm{C}$, compared with $37{ }^{\circ} \mathrm{C}$, which is the core body temperature in these species $[50,51]$. Although these latter studies also point to the beneficial effects of culturing testis cells at lower than core body temperature, they each examined only one such temperature, making it difficult to compare the results. Results from the present study suggest that further studies will be required to determine the optimal temperature for culturing testis cells for a given species.

The use of poly-L-lysine-coated coverslips is recommended when sampling cultured testis cells. Opposing ionic charges among the cells (polyanionic) and poly-Llysine-coated coverslip surface (polycationic) enhance efficient attachment of cells onto the coverslips. In the present study, we showed that 1) the presence of poly-Llysine-coated coverslips had no adverse effects on the growth of cultured testis cells; 2) cells did not grow on non-coated coverslips; and 3) there was no difference in cell viability between the cells growing on coverslips and the peripheral areas of the well. Therefore, while coverslips placed at the bottom of round plate wells provide a convenient method of sampling for analyses such as immunocytochemistry, the cells at the peripheral areas could also be used for other evaluations such as monitoring of the cell viability or use in other assays. Using coverslips also offers the advantage of allowing multiple samplings from the culture dish with minimal disturbance to other cells in the same dish/plate.

In vivo proliferation of gonocytes is influenced by their contact or interaction with the basement membrane of the seminiferous tubule [52]. It has also been suggested that gonocytes require the presence of feeder cells in order to settle and form colonies in vitro $[26,53-56]$. In the present study, testis somatic cells formed a monolayer, which provided a platform for subsequent gonocyte attachments. It also appeared that the survival and propagation of gonocytes depended on the proper ratio of gonocytes to somatic cells. This was exemplified in Experiment 1, where we used highly enriched gonocytes $(\sim 86 \%)$ for seeding and observed no or slow cell proliferation, even when the enriched gonocytes were used at 
the same seeding density $\left(3.0 \times 10^{5} /\right.$ well $)$ as heterogeneous populations of testis cells. This is in agreement with a previous study by van Dissel Emiliani et al. [57] showing that when gonocytes were cultured alone, they failed to adhere to the culture plate and instead formed gonocyte aggregates, which were subsequently lost.

In fetal and neonatal testes, gonocytes are larger than most testis cells and one would expect that among testis cells in the suspension, gonocytes would be one of the first cells to settle. This was indeed the case for mouse fetal gonocytes showing the highest sedimentation velocity of all testis cells [27]. In the present study, however, gonocytes settled much later than other testis cells, and could be seen floating even after several days of culture. Goel et al. [58] examined the population of floating cells after $4 \mathrm{~h}$ of culturing neonatal pig testis cells and concluded that they were mostly viable ( $95 \%)$ and composed of mostly germ cells (91\%). In the present study, although the number of floating gonocytes decreased over time, their viability remained high $(78-86 \%)$ up to $6 \mathrm{~d}$ after culture. The extended presence of floating gonocytes may be an advantageous characteristic if they are collected to be used for gonocyte enrichment; however, it can also be disadvantageous and lead to the loss of gonocytes during medium changes, if done without due care.

Changing of medium is important to furnish nutrients and remove waste from a culture system; however, the frequency of medium changing may affect culture conditions. Most studies on testis cell culture use a daily, every-other-day, or twice-weekly approach to medium changing $[18,42,57,59,60]$. In the present study, routine changing of medium (every $2 \mathrm{~d}$ ) reduced the number of attached gonocytes, prompting us to design Experiment 6 for optimizing the medium changing regimen to increase the number of gonocyte colonies. Given our observations of the floating gonocytes, we compared gonocyte colony formation following the routine medium changing regimen (every $2 \mathrm{~d}$ ) with the group in which the medium was not changed for 1 wk., or with the modified medium changing regimen, where a smaller volume of medium was exchanged at a time. Compared with Day $2\left(\sim 5.0 \times 10^{3}\right)$, the number of gonocytes and gonocyte colonies increased in all regimens in subsequent days (Days 4, 6, and 7; Fig. 5). The increased number of gonocyte colonies on Day 4 in all groups (ranging from $\sim 10.0 \times 10^{3}$ to $\sim 13.5 \times 10^{3}$, Fig. 5) could be taken as evidence of gonocyte proliferation in these early days of culture. This conclusion is especially based on the plates in the routine medium changing regimen which had undergone a complete medium change. As a result, this group of plates presumably should have lost all or most of its floating gonocytes, yet there was a 2-fold increase in the number of gonocyte colonies. On the other hand, the number of gonocyte colonies in subsequent days (6 and 7) were $~ 50 \%$ greater in the unchanged group, compared with the routine medium changing regimen $\left(\sim 18.0 \times 10^{3}\right.$ vs. $\sim 12 \times 10^{3}$, respectively, Fig. 5$)$. This can be seen as evidence of continued settlement of gonocytes. The number of gonocyte colonies also increased over time in all groups; this increase was $\sim 3.3$ fold for the unchanged medium group (from $\sim 5.4 \times 10^{3}$ on Day 2 to $\sim 18.0 \times 10^{3}$ on Day 7, Fig. 5). This foldincrease in the total number of gonocyte colonies does not take into account that the number of gonocytes within each colony also increased over time (Fig. 3d). Therefore, these results collectively indicate that the optimized culture conditions developed in the present study improved gonocyte colony formation.

In the present study, we systematically examined the effects of several culture conditions on testis cells of the neonatal pig, as a non-rodent animal model. After each experiment, we built upon the newly obtained results and designed subsequent experiments to make successive advances in the survival, propagation, and colony formation of gonocytes. Our results are expected to facilitate further studies aiming at, for instance, investigation of specialized media for large-scale propagation of gonocytes, as a source of MGSCs. Applications for MGSCs range from basic to applied research, including germ cell transplantation studies in farm animals for the purpose of animal transgenesis, genetic conservation, or infertility treatment models [4, 5, 33-35]. Germ cell transplantation can also be used as a functional assay to assess the relative abundance or confirm the developmental potential of MGSCs within a given population of testis cells, including cultured gonocytes (reviewed in [31]).

\section{Conclusions}

In conclusion, the optimized culture conditions developed in the present study included seeding neonatal porcine testis cells at $3.0 \times 10^{4}$ testis cells $/ \mathrm{cm}^{2}$ containing $\sim 40 \%$ gonocytes in $\mathrm{DMEM}^{++}$at $37^{\circ} \mathrm{C}$, and without changing the medium in the first week. These results can be used to improve in vitro maintenance, proliferation, and formation of gonocyte colonies and thereby as a basis for the development of more specialized culture systems for MGSCs.

\footnotetext{
Abbreviations

ANOVA: Analysis of variance; DAPI: 4',6-diamidino-2-phenylindole; DAZL: Deleted in azoospermia like; DBA: Dolichos biflorus agglutinin; DMEM: Dulbecco's modified Eagle medium; DMEM ${ }^{++}$: DMEM supplemented with 10\% fetal bovine serum and 1\% antibiotics; DPBS: Dulbecco's phosphate-buffered saline; ECM: Extracellular matrix; FBS: Fetal bovine Serum; H\&E: Hematoxylin and Eosin; HBSS: Hank's balanced salt solution; $\mathrm{HCl}$ : Hydrochloric acid; HSD: Honest significant difference; $\mathrm{KHCO}_{3}$ : Potassium bicarbonate; MGSCs: Male germline stem cells; NA ${ }_{2}$ EDTA: Disodium ethylenediaminetetraacetate; NANOG: NANOG homeobox;

$\mathrm{NH}_{4} \mathrm{Cl}$ : Ammonium chloride; OCT4: Octamer-binding transcription factor 4; PGCs: Primordial germ cells; PGP9.5: Protein gene product 9.5; SEM: Standard error of mean; SPSS: Statistical package for the social sciences; SSCs: Spermatogonial stem cells; UCH-L1: Ubiquitin carboxyl-terminal hydrolase L1; VASA: Dead-box helicase 4
} 


\section{Acknowledgements}

We thank Brian Andries and his staff, especially Tatjana Ometlic, at the Prairie Swine Centre for their assistance in the collection of neonatal porcine testes. We also thank Shawn Honaramooz for help with cell culture and Willow Burnes for proofreading the revised manuscript.

\section{Funding}

This project was financially supported by grants from the Natural Science of Engineering Research and Council (NSERC) of Canada awarded to A. Honaramooz. Graduate student scholarships to A.H. Awang-Junaidi were provided by the Ministry of Higher Education of Malaysia, the University of Saskatchewan College of Graduate and Postdoctoral Studies, and the University of Saskatchewan Western College of Veterinary Medicine.

\section{Availability of data and materials}

The datasets supporting the conclusions of this article are included within the article. For additional information please contact author.

\section{Authors' contributions}

AHAJ contributed to the conceiving and designing of the study, performed the experiments and wrote the first draft of the manuscript; $\mathrm{AH}$ contributed to the conceiving and designing of the study, as well as writing and revising the manuscript. Both authors read and approved the final manuscript.

\section{Ethics approval}

All experimental procedures involving animals were approved by the University of Saskatchewan's Institutional Animal Care and Use Committee (Protocol\# 20080042).

\section{Consent for publication}

Not applicable. Portions of this study were presented in the form of an abstract at the 41st American Society of Andrology annual conference.

\section{Competing interests}

The authors declare that they have no competing interest.

Received: 25 April 2017 Accepted: 19 December 2017

Published online: 17 January 2018

\section{References}

1. Lehmann R. Germline stem cells: origin and destiny. 10. Cell Stem Cell. 2012; 10(4):729-39.

2. Brinster RL, Avarbock MR. Germline transmission of donor haplotype following spermatogonial transplantation. Proc Natl Acad Sci U S A. 1994; 91(24):11303-7.

3. Jiang FXU, Short RV. Different fate of primordial germ cells and gonocytes following transplantation. APMIS. 1998;106(1):58-63. https://doi.org/10.1111/ j.1699-0463.1998.tb01319.x.

4. Honaramooz A, Megee SO, Dobrinski I. Germ cell transplantation in pigs. Biol Reprod. 2002;66(1):21-8.

5. Honaramooz A, Behboodi E, Blash S, Megee SO, Dobrinski I. Germ cell transplantation in goats. Mol Reprod Dev. 2003;64(4):422-8.

6. Honaramooz A, Behboodi E, Megee SO, Overton SA, Galantino-Homer H Echelard $Y$, et al. Fertility and germline transmission of donor haplotype following germ cell transplantation in immunocompetent goats. Biol Reprod. 2003;69(4):1260-4.

7. Izadyar F, Den Ouden K, Stout TAE, Stout J, Coret J, Lankveld DPK, et al. Autologous and homologous transplantation of bovine spermatogonial stem cells. Reproduction. 2003;126(6):765-74.

8. Herrid M, Olejnik J, Jackson M, Suchowerska N, Stockwell S, Davey R, et al. Irradiation enhances the efficiency of testicular germ cell transplantation in sheep. Biol Reprod. 2009;81(5):898-905.

9. Chuma S, Kanatsu-Shinohara M, Inoue K, Ogonuki N, Miki H, Toyokuni S, et al. Spermatogenesis from epiblast and primordial germ cells following transplantation into postnatal mouse testis. Development. 2005;132(1):117-22.

10. Kim KJ, Cho CM, Kim BG, Lee YA, Kim BJ, Kim YH, et al. Lentiviral modification of enriched populations of bovine male gonocytes. J Anim Sci. 2014;92(1):106-18

11. Ohta H, Wakayama T, Nishimune Y. Commitment of fetal male germ cells to spermatogonial stem cells during mouse embryonic development. Biol Reprod. 2004;70(5):1286-91.
12. De Rooij DG. Proliferation and differentiation of spermatogonial stem cells. Reproduction. 2001:121:347-54.

13. Orwig KE, Shinohara T, Avarbock MR, Brinster RL. Functional analysis of stem cells in the adult rat testis. Biol Reprod. 2002;66(4):944-9.

14. Grisanti L, Falciatori I, Grasso M, Dovere L, Fera S, Muciaccia B, et al. Identification of spermatogonial stem cell subsets by morphological analysis and prospective isolation. Stem Cells. 2009;27(12):3043-52. https://doi.org/ 10.1002/stem.206

15. De Rooij DG, Russell LD. All you wanted to know about spermatogonia but were afraid to ask. J Androl. 2000;21:776-98. https://doi.org/10.1002/j.19394640.2000.tb03408.x.

16. Oatley JM, Brinster RL. Regulation of spermatogonial stem cell self-renewal in mammals. Annu Rev Cell Dev Biol. 2008;24:263-86.

17. Culty M. Gonocytes, the forgotten cells of the germ cell lineage. Birth Defects Res C Embryo Today. 2009:87(1):1-26. https://doi.org/10.1002/bdrc.20142.

18. Goel S, Sugimoto M, Minami N, Yamada M, Kume S, Imai H. Identification, isolation, and in vitro culture of porcine gonocytes. Biol Reprod. 2007;77(1):127-37.

19. Yang $Y$, Honaramooz A. Characterization and quenching of autofluorescence in piglet testis tissue and cells. Anat Res Int. 2012;2012: 820120. https://doi.org/10.1155/2012/820120.

20. Zogbi C, Tesser RB, Encinas G, Miraglia SM, Stumpp T. Gonocyte development in rats: proliferation, distribution and death revisited. Histochem Cell Biol. 2012;138(2):305-22.

21. Orwig KE, Ryu B-Y, Avarbock MR, Brinster RL. Male germ-line stem cell potential is predicted by morphology of cells in neonatal rat testes. Proc Natl Acad Sci U S A. 2002;99(18):11706-11.

22. Honaramooz A, Behboodi E, Hausler CL, Blash S, Ayres S, Azuma C, et al. Depletion of endogenous germ cells in male pigs and goats in preparation for germ cell transplantation. J Androl. 2005;26(6):698-705.

23. Dobrinski I, Avarbock MR, Brinster RL. Transplantation of germ cells from rabbits and dogs into mouse testes. Biol Reprod. 1999;61(5):1331-9.

24. Shinohara T, Orwig KE, Avarbock MR, Brinster RL. Spermatogonial stem cell enrichment by multiparameter selection of mouse testis cells. Proc Natl Acad Sci U S A. 2000;97(15):8346-51.

25. van den Ham R, van Pelt AM, de Miguel MP, van Kooten PJ, Walther N, van Dissel-Emiliani FM. Immunomagnetic isolation of fetal rat gonocytes. Am J Reprod Immunol. 1997 Jul;38(1):39-45.

26. Borjigin U, Zhou X, Han X, Li R, Herrid M, Bou S. Enrichment and short term culture of the ovine gonocyte. J Anim Vet Adv. 2011;10(22):2936-42. http:// docsdrive.com/pdfs/medwelljournals/javaa/2011/2936-2942.pdf

27. van Dissel-Emiliani FM, Grootenhuis AJ, De Jong FH, De Rooij DG. Inhibin reduces spermatogonial numbers in testes of adult mice and Chinese hamsters. Endocrinology. 1989;125(4):1898-903.

28. Li H, Papadopoulos V, Vidic B, Dym M, Culty M. Regulation of rat testis gonocyte proliferation by platelet-derived growth factor and estradiol: identification of signaling mechanisms involved. Endocrinology. 1997;138(3):1289-98.

29. Yang Y, Yarahmadi M, Honaramooz A. Development of novel strategies for the isolation of piglet testis cells with a high proportion of gonocytes. Reprod Fertil Dev. 2010:22(7):1057-65.

30. Yang $Y$, Honaramooz A. Efficient purification of neonatal porcine gonocytes with Nycodenz and differential plating. Reprod Fertil Dev. 2011;23(3):496-505

31. Honaramooz A, Yang Y. Recent advances in application of male germ cell transplantation in farm animals. Vet Med Int. 2010;2011:657860. https://doi.org/10. 4061/2011/657860

32. Honaramooz A. Cryopreservation of testicular tissue. In: Katkov I, editor. Current frontiers in cryobiology. Rijeka: INTECH; 2012. p. 209-28. ISBN: 978-953-51-0191-8.

33. Honaramooz A, Megee S, Zeng W, Destrempes MM, Overton SA, Luo J, et al. Adeno-associated virus (AAV)-mediated transduction of male germ line stem cells results in transgene transmission after germ cell transplantation. FASEB J. 2008;22(2):374-82

34. Zeng W, Tang L, Bondareva A, Honaramooz A, Tanco V, Dores C, et al. Viral transduction of male germline stem cells results in transgene transmission after germ cell transplantation in pigs. Biol Reprod. 2013; 88(1):27,1-9.

35. Mankidy R, Ranjan B, Honaramooz A, Giesy JP. Effects of novel brominated flame retardants on steroidogenesis in primary porcine testicular cells. Toxicol Lett. 2014:224(1):141-6.

36. Yang $Y$, Honaramooz A. Effects of medium and hypothermic temperatures on preservation of isolated porcine testis cells. Reprod Fertil Dev. 2010;22(3):523-32. 
37. Reijo R, Alagappan RK, Patrizio P, Page DC. Severe oligozoospermia resulting from deletions of azoospermia factor gene on Y chromosome. Lancet. 1996; 347(9011):1290-3.

38. Castrillon DH, Quade BJ, Wang TY, Quigley C, Crum CP. The human VASA gene is specifically expressed in the germ cell lineage. Proc Natl Acad Sci U S A. 2000:97(17):9585-90.

39. Anderson R, Fulton N, Cowan G, Coutts S, Saunders PT. Conserved and divergent patterns of expression of DAZL, VASA and OCT4 in the germ cells of the human fetal ovary and testis. BMC Dev Biol. 2007;7(February):136.

40. Fujihara M, Kim S-M, Minami N, Yamada M, Imai H. Characterization and in vitro culture of male germ cells from developing bovine testis. J Reprod Dev. 2011;57(3):355-64.

41. Kim B-G, Cho CM, Lee Y-A, Kim B-J, Kim K-J, Kim Y-H, et al. Enrichment of testicular gonocytes and genetic modification using lentiviral transduction in pigs. Biol Reprod. 2010;82(6):1162-9.

42. Han SY, Gupta MK, Uhm SJ, Lee HT. Isolation and in vitro culture of pig spermatogonial stem cell. Asian-Australasian J Anim Sci. 2009;22(2):187-93.

43. Baschong W, Suetterlin R, Laeng RH. Control of autofluorescence of archival formaldehyde-fixed, paraffin-embedded tissue in confocal laser scanning microscopy (CLSM). J Histochem Cytochem. 2001;49(12):1565-72.

44. Schnell SA, Staines WA, Wessendorf MW. Reduction of lipofuscin-like autofluorescence in fluorescently labeled tissue. J Histochem Cytochem. 1999:47(6):719-30.

45. Hess RA, Moore BJ. Histological methods for evaluation of the testis. In: Chapin RE, Heindel JJ, editors. Methods in toxicology, Vol. 3, pt. A. Male reproductive toxicology. San Diego: Academic Press; 1993. p. 86-94.

46. Howroyd P, Hoyle-Thacker R, Lyght O, Williams D, Kleymenova E. Morphology of the fetal rat testis preserved in different fixatives. Toxicol Pathol. 2005;33(2):300-4.

47. Xia Y, Prawirasatya M, Heng BC, Boey F, Venkatraman SS. Seeding density matters: extensive intercellular contact masks the surface dependence of endothelial cellbiomaterial interactions. J Mater Sci Mater Med. 2011;22(2):389-96.

48. Ingram $\mathrm{D}$, Legge $\mathrm{K}$. The thermoregulatory behavior of young pigs in a natural environment. Physiol Behav. 1970;5:981-7.

49. Lohse L, Uttenthal A, Enøe C, Nielsen J. A study on the applicability of implantable microchip transponders for body temperature measurements in pigs. Acta Vet Scand. 2010;52:29.

50. Zhou Q, Nie R, Li Y, Friel P, Mitchell D, Hess R. A, et al. expression of stimulated by retinoic acid gene 8 (Stra8) in spermatogenic cells induced by retinoic acid: an in vivo study in vitamin A-sufficient postnatal murine testes. Biol Reprod. 2008;79(March):35-42.

51. Nakamura M, Namiki M, Okuyama A, Matsui T, Doi Y, Takeyama M, et al. Temperature sensitivity of human spermatogonia and spermatocytes in vitro. Arch Androl. 1987;19:127-32.

52. McGuinness MP, Orth JM. Reinitiation of gonocyte mitosis and movement of gonocytes to the basement membrane in testes of newborn rats in vivo and in vitro. Anat Rec. 1992:233(4):527-37.

53. Nagano M, Ryu BY, Brinster CJ, Avarbock MR, Brinster RL. Maintenance of mouse male germ line stem cells in vitro. Biol Reprod. 2003;68:2207-14.

54. Orth JM, McGuinness MP. Neonatal gonocytes co-cultured with Sertoli cells on a laminin-containing matrix resume mitosis and elongate. Endocrinology. 1991;129(2):1119-21.

55. Hasthorpe S, Barbic S, Farmer PJ, Hutson JM. Neonatal mouse gonocyte proliferation assayed by an in vitro clonogenic method. J Reprod Fertil. 1999:116(2):335-44.

56. Kanatsu-Shinohara M, Ogonuki N, Inoue K, Miki H, Ogura A, Toyokuni S, et al. Long-term proliferation in culture and germline transmission of mouse male germline stem cells. Biol Reprod. 2003;69(2):612-6.

57. van Dissel-Emiliani FM, de Boer-Brouwer M, Spek ER, van der Donk JA de Rooij DG. Survival and proliferation of rat gonocytes in vitro. Cell Tissue Res. 1993;273:141-7.

58. Goel S, Fujihara M, Minami N, Yamada M, Imai H. Expression of NANOG, but not POU5F1, points to the stem cell potential of primitive germ cells in neonatal pig testis. Reproduction. 2008;135(6):785-95.

59. Joffre BYM, Roche A. Follicle-stimulating hormone induces hyperpolarization of immature rat Sertoli cells in monolayer culture. J Physiolo. 1988;400:481-99.

60. Majumdar SS, Tsuruta J, Griswold MD, Bartke A. Isolation and culture of Sertoli cells from the testes of adult Siberian hamsters: analysis of proteins synthesized and secreted by Sertoli cells cultured from hamsters raised in a long or a short photoperiod. Biol Reprod. 1995;52(3):658-66.

\section{Submit your next manuscript to BioMed Central and we will help you at every step:}

- We accept pre-submission inquiries

- Our selector tool helps you to find the most relevant journal

- We provide round the clock customer support

- Convenient online submission

- Thorough peer review

- Inclusion in PubMed and all major indexing services

- Maximum visibility for your research

Submit your manuscript at www.biomedcentral.com/submit
Biomed Central 